\title{
Editorial
}

\section{Letras que fogem e encontros que se fazem}

O convite para escrever o prefácio da uma obra, em qualquer gênero textual, seja um livro ou uma revista como esta, é sempre um desafio, pois significa, além de mergulhar em intensas reflexões que qualquer escrita nos impõe, tecer várias indagações: por onde começar? Quais palavras serão escolhidas? Que caminhos trilhar? O que será escrito?

Essa situação se torna mais difícil quando se trata de um periódico situado em outro país e em outra língua, que mesmo próximos, pode nos dar a sensação de como as geografias que se forjam nas relações do mundo e no campo da linguagem são relevos irregulares a serem vividos e percorridos.

Confesso, assim, ao leitor que está percorrendo minhas palavras por essas linhas iniciais, que é este o exato momento que estava vivendo! As letras se compunham em vocábulos, em lentos movimentos, elas surgiam, desapareciam e pareciam não querer se envolver comigo. A dimensão de exotopia que Bakhitn (2011) apontou como necessário para que acontecer o ato estético da produção literária, marcada pelo deslocar de sua consciência para além de si mesmo e que permite ao autor vislumbrar de outro ponto sua criação, teimava em não acontecer.

Mas, quando as letras se desejam tornar fugidias, almejam não estar por perto, para mim só há uma possibilidade: recorrer à literatura, esse é um caminho que sempre me salva, já que a poesia das obras criadas parece afagar os vocábulos e com isso eles voltam a se aproximar, regressam novamente e com esse chegar perto, possibilitam o afastar que gera as fronteiras do ato de criação. Com isso, caro leitor, lembro que qualquer escritor vive sempre essa condição geográfica: a de estar perto e longe ao mesmo tempo, só essa metáfora espacial, uma divisa que é encontro, outorga a imaginação, seja ela literária ou acadêmica.

Como falo do Brasil. Esse é o território de onde emerge meu texto, escolho a literatura brasileira. E resgato uma obra que está sempre presente em meus trabalhos, falo de livros que me afeiçoaram e aprendi afeiçoar desde minha infância, falo de um do escritor mineiro ${ }^{1}$ conhecido por Guimarães Rosa. E como escrevo para outro país, creio ser uma gentileza a explicar para aqueles que não conhecem quem é escritor, não com o intuito de fazer um fechamento em torno dessa pessoa, mas, exatamente o contrário, uma abertura para novas buscas e descobertas.

Guimarães Rosa nasceu na cidade de Codisburgo, um espaço urbano considerado pequeno pelo número de habitantes que ainda vivem ai hoje, em torno de 9000 pessoas. Era o ano de 1908, portanto, viveu a maior parte de sua vida na primeira metade do século XX, já que faleceu aos 59 anos. A sua cidade natal, localizada no estado de Minas Gerais, e as paisagens geográficas que fazem parte dessa região marcaram de forma intensa suas obras. Uma de suas mais conhecidas "Grande Sertão Veredas" é, exatamente, a que escolho para ser minha referência aqui. 
Em "Grande Sertão: Veredas" encontramos Riobaldo e Diadorim, nome de dois personagens, entre os muitos outros presente na história redigida por esse escritor. E é acompanhando a vida do primeiro, que toda a travessia da narrativa acontece e nela se cruzam muitas outras biografias e temporalidades, muitos eventos e acontecimentos, mas algo permanece perene: a paisagem do sertão onde os episódios se desdobram.

O sertão é uma expressão de cunho espacial, faz referencia ao cerrado, uma forma de vegetação presente nessa área de Minas Gerais, mas ao mesmo tempo é muito mais que isso, na obra desse autor é uma forma de existir no mundo. É bem conhecida vária de suas passagens presentes nesse livro: "O sertão aceita todos os nomes: aqui é o Gerais, lá é o Chapadão, lá acolá é a caatinga. (IBIDEM, p.701); ou ainda "O sertão não tem janelas nem portas. E a regra é assim: ou o senhor bendito governa o sertão, ou o sertão maldito vos governa..." (IBIDEM, p.709)

É assim que as palavras se encontram com os lugares, com os tempos e se fazem como linguagens que criam a vida e as pessoas. O sertão se reinventa a cada leitura, se torna eterno como literatura, mas está sempre em constante renovação. Nesse movimento de renovar-se, renovam aqueles que por ele caminham.

E nesse ponto, há outro encontro: a tarefa que me foi dada e que todos esses ditos iniciais não podem cobrir: a de apresentar essa revista. Por isso escolhi essa narrativa, não apenas para salvar a minha escrita, como comentei anteriormente, isso já ocorreu, vejam quantas linhas foram construídas até esse momento, mas também porque creio que ela ajuda a compreender a força que todo o texto, como os que estão disponíveis nas páginas que seguem a esse prefácio, apresentam na formação e renovação dos outros e outras que os lêem, como sempre são verdadeiros sertões no sentido expresso por Guimarães Rosa.

Tradicionalmente, como aquele que está convidado a abrir essa revista, eu deveria fazer uma pequena apresentação de cada texto e quiçá de seus autores, talvez, ainda, um pequeno resumo para que o leitor pudesse ter uma visão geral de todo o material, mas, preciso dizer, que essa não será minha escolha. Quem chegou até aqui, com certeza já passou pelo sumário e pelos autores, já devem ter escolhidos alguns a que irão se dedicar primeiro. Além disso, todo periódico acadêmico obriga a existência de um resumo e de palavras-chaves. Um olhar para essas partes já permitem conhecer muito do que virá e criam o desejo da escolha prévia, já estão aqui.

Portanto me permito a citar os títulos dos artigos, vejamos: "Diseño y aplicación de secuencias didacticas para fortalecer el aprendizaje de los números enteros y operaciones basicas: suma y multiplicación en estudiantes de septimo grado de la institución educativa juan Pablo"; "Borges y la matemática"; "La invisibilización de las mujeres en la academia"; De la didáctica general a la didáctica del idioma inglés como lengua extranjera"; "El modelo pedagógico en el área de tecnología e informática y la plataforma edmodo en la institución educativa distrital Reuven Feuerstein"; "Prácticas de los estudiantes en el espacio de la cafetería de un colegio público", "Educar para la paz, perdón y reconciliación"; "Una experiencia desde las pedagogias para la paz y la Educación Artística"; "Horror al vacio 'neobarroco': los diseños de las 'chivas' de San Sgustín y La Plata". Olhe para ele como

\footnotetext{
${ }^{1}$ Ser "mineiro" é um adjetivo gentílico, faz referência aos territórios de nascimento das pessoas, no caso do Brasil, referese as pessoas que nascem no estado de Minas Gerais.
} 


\section{Editorial}

palavras que são as chaves de possíveis leituras, como os sertões que poderão criar longas e prazerosas caminhadas, como fluxos de rios que escorrem e transformam.

Lembremos o que é mais importante e significativo na produção de qualquer escrita: elas portam saberes e esses devem ser olhados como patrimônios universais. Como direito aos conhecimentos, que se ressoam em potencias de mudanças da vida humana da sociedade. Esse é o sentido em torno do qual os artigos aqui se encontram, esse é o sentido que deveria estar presente em qualquer periódico acadêmico.

Falei de Guimarães Rosa nos parágrafos iniciais desse prefácio e do poder da palavra como encontro, para fechar convido todos e todas a se encontrarem com outro brasileiro, Paulo Freire (1989) e a sua defesa constante que envolve a importância do ato de ler a vida e as escritas que nela existem:

A leitura do mundo precede a leitura da palavra, daí que a posterior leitura desta não possa prescindir da continuidade da leitura daquele. Linguagem e realidade se prendem dinamicamente. A compreensão do texto a ser alcançada por sua leitura crítica implica a percepção das relações entre o texto e o contexto. Ao ensaiar escrever sobre a importância do ato de ler, eu me senti levado - e até gostosamente - a "reler" momentos fundamentais de minha prática, guardados na memória, desde as experiências mais remotas de minha infância, de minha adolescência, de minha mocidade, em que a compreensão critica da importância do ato de ler se veio em mim constituindo. (p.09)

Boas leituras.

\section{Referencias}

Bakthin, Mikhail. Estética da criação verbal. Tradução: Paulo Bezerra. 6. ed. São Paulo: MartinsFontes, 2011.

Rosa, Guimarães. Grande Sertão Veredas. Disponível em: http://stoa.usp.br/carloshgn/files/-1/20292/GrandeSertoVeredasGuimares

Rosa.pdf Acesso em: 10 de julho de 2020. Freire, Paulo. A importância do ato de ler: em três artigos que se completam São Paulo: Autores Associados: Cortez, 1989. 